\title{
DOI 10.26886/2414-634X.2(21)2018.13
}

UDC 371.124

\section{CONTENT AND STRUCTURE OF THE CATEGORY "PROFESSIONAL SOCIALIZATION OF FUTURE TEACHER- PEDAGOGUE"}

\section{V. Firsova}

Volodymyr Vynnychenko Central Ukrainian State Pedagogical University, Ukraine, Kropyvnytskyi

In the reviewed article on the basis of the study of scientific literature, the author attempts to analyze the main approaches to the issue of professional socialization of the future teacher-pedagogue, which is differently interpreted in psychological and pedagogical circles. Therefore, finding out its content and structure is relevant and requires a clear definition. Particular attention has been paid to studying the connection of this category with the phenomena of self-actualization and selfconsciousness of the individual, which are increasingly becoming the object of psychological research. The purpose of this article is to analyze the approaches of the paradigm of psychological and pedagogical research to determine the content and structure of the professional socialization of the personality of the future teacher-pedagogue. The process of professional socialization of the individual in the unity of various planes of the implementation of elements of self-consciousness has been considered; the structure and basic mechanisms of socialization of the personality have been determined; the tendencies of psychological and pedagogical scientific thought regarding the interpretation of the category of professional socialization have been researched. It has been found out that the professional socialization of the future teacher-pedagogue has its own specificity, which manifests itself primarily in reducing self-actualization and 
increasing prosociality.

Key words: personality, socialization, professional socialization, professional socialization of future teacher-pedagogue.

Фирсова И. В. Содержание и структура категории «профрессиональная социализация будущего преподавателяпедагога» / Центральноукраинский государственный педагогический университет имени Владимира Винниченко, Кропивницький, Украина.

В рецензируемой статье на основе изучения научной литературы автором предпринимается попытка анализа основных подходов к вопросу профрессиональной социализации будущего преподавателя-педагога, которая неоднозначно толкуется 6 психологических и педагогических кругах, поэтому выяснение ее содержания и структуры является актуальным и требующим четкого определения. Особое внимание уделяется изучению связи этой категории с феноменами самоактуализации и самосознания личности, что все чаще становятся объектом психологических исследований. Целью этой статьи является анализ подходов парадигмы психолого-педагогических исследований к определению содержания и структуры категории профрессиональной социализации личности будущего преподавателя-педагога, которая реализована путем решения следующих задач: рассмотрен процесс профрессиональной социализации личности в единстве различных плоскостей осуществления элементов самосознания; определена структура и основные механизмы социализации личности; исследованы тенденции психолого-педагогической научной мысли относительно толкования категории профрессиональной социализации. Сделано вывод, что профессиональная социализация педагога имеет свою специфику, которая проявляется прежде всего в снижении самоактуализации и усилении просоциальности. 
Ключевые слова: личность, социализация, профрессиональная социализация, профрессиональная социализация будущего преподавателя-педагога.

Introduction. At each new age stage, a person enters a new social microenvironment, which has a complex structure, evolving from monogroup structure to poly-group one. Movement of the person along the vertical life path, associated with the change in group situations of the microenvironment, generates, on the one hand, a qualitatively defined destined structure of the personality, and on the other hand - the problem of the formation in it social and psychological readiness for new types of communication and activity.

Socialization refers to the process of incorporating a growing person into society through the assimilation and reproduction of social experience, historically accumulated culture by a personality. The purpose here is to develop the personality who is capable of empathy, ready for a free, humanistic choice and individual intellectual effort, a person who respects oneself and others, tolerant of representatives of other cultures and nationalities, independent in judgment, open to another and unexpected thought.

The purpose of this article is to analyze the approaches of the paradigm of psychological and pedagogical research to determining the category of self-determination, which has been realized by solving the following tasks: the process of self-determination of personality in the unity of various planes of self-actualization has been considered; different types of self-determination have been identified in accordance with the main spheres of personality life; trends of psychological and pedagogical scientific thought regarding the interpretation of the category of selfdetermination have been researched. 
Socialization - the formation of personality in a certain culture, in one or another social system. Individualization - deployment of its own internal development program. Human development is the interweaving of two independent processes - socialization and individualization. Where socialization is the art of being like everyone, and individualization is the art of being oneself. Socialization is what makes people alike. Individualization helps them to become different. Individualization is a more "mature" process.

Consideration of the process of socialization of the individual is not possible without the characteristics of the person itself. As noted by E. E. Sokolova, “... in today's world psychology there are at least three different in terms of definition personalities. According to the first approach the most common in world psychology, the concept of personality coincides with the concept of the subject, that is, contains all the natural and social features of an individual. ... The second definition of personality - the narrower - contains only the social qualities of the individual, acquired by them in a concrete historical system of social relations" [15, p.83]. The third approach, proposed by followers of the school of O. M. Leontiev, introduces the criterion of the external and internal conditionality of the behavior and consciousness of the subject acts in the form of "external determination" external to the human deep existential I, and completely different - when the relationship of the subject with the world reach a new level of regulation the level of self-determination. According to V.V.Petukhov and $\mathrm{V}$. V. Stolin in the first case one needs to speak not about the person, but about the social subject, in the second case, about the person " [15, p.84].

Social groups cannot exist outside professional groups. Getting an individual in a particular profession, as a rule, means his entry, and then belonging to a particular social group or stratum. 
From the point of view of the functioning of the group as a team and the application of various technologies to it, it is undeniably worth appealing to the studies of A. S. Makarenko. In his writings, he clearly, as of his time, realized the important methodological principles of research of the social group. He understood the team as "a socially living organism, which is why the body, that it has organs, that there is power, responsibility, proportion of parts, interdependence ..." [9, p. 56].

In the context of the concept of the integral social nature (essence) of human, socialization appears as a holistic process, a specific function and modality of human nature and results in the potential universality and diversity of an individual. The mechanisms of increasing socialization of a person are: ability to identify oneself with others, allowing them to determine and take new content from another (person, group, society); ability to individualize own self (separation), which allows one to make this content its own - personified in accordance with the level of development of its corporeality, cognition, emotional-volitional sphere [16, 17].

Under the professional socialization of the future teacher-pedagogue, we mean mastering the socio-professional experience in conditions of a purposeful, specialized organization, which manifests itself as a set of all educational influences.

In the process of professional socialization, such parameters of selfactualization as contact, creativity and flexibility are all the most affected and tending to decrease. In addition, the indicator of the support scale decreases, indicating an increase in dependency, conformality, orientation towards others, and orientation towards social norms. That is, the professional socialization of the teacher has its own specificity, which manifests itself primarily in reducing self-actualization and increasing prosociality. 
In the process of professional socialization, the system of priorities is changing: from relationships with pupils, then - with colleagues, to selfactualization. In the period of maturity, self-actualization and personality satisfaction are most integrated. Socialization of personality, considered as mastering social experience in the conditions of its purposeful, specialized organization (professional training), is manifested as a set of all educational influences. Thus, socialization on the one hand - as a result, implies the mastering of certain knowledge, models and behavioral patterns in accordance with the universally recognized system of values, thereby promoting integration into public life. On the other hand, socialization objectively restricts the prospects of personal development, since the norms and rules established by the society, educational standards and other "braking" offset its individual manifestations.

The ideas of anthropologization of modern theory and practice of education, the concept of socialization, education and development of the child's personality have found their development in the studies of
V. S. Bibler,
B. Z. Wolfov, V. V. Davydov,
I. P. Ivanov,
D. V. Kolesov,
V. M. Korotova,
V. V. Krayevsky,
O. M. Leontiev,
A. V. Petrovsky,
D. B. Elkonin and others.

The range of evaluations, views, approaches, concepts of socialization is quite varied. However, to give an exhaustive answer to the questions that constitute the problem of socialization of man, it is possible only on the ways of integrating scientific knowledge and holistic approach to the child, as well as focusing on the humanization of the education itself.

Summarizing the aforementioned under the professional socialization of the individual, we understand the process of its adaptation to the conditions and characteristics of professional formation. The professional socialization of the individual is determined by the intensity, depth and diversity of interrelations. 
G. S. Saliven considers personality as an energy system whose activity reduces stress [14]. One of the components of personality is dynamism stable patterns of transformed energy. An important dynamism associated with interpersonal relationships is the dynamism of "I," or the system of "I".

The problem of personality, the ways of its formation leads the researcher to the next level of philosophical, social, concepts, theories of education, etc. Thus, in particular, in the process of personal socialization, an experience of understanding their capabilities and abilities necessary to achieve a life's purpose is formed. "The purpose is the result that is provided in the mind, accessible to the understanding of the subject, as well as - other people" [11, p.278].

Expanding the content characteristics of man, one can not but pay attention to the perception and understanding of it itself, the attitude towards oneself and behavior in the environment of life. Every person at a certain moment of life has a contemplative image of herself, taking possession of one or another personality traits and specific properties of herself as units of activity, simultaneously revealing more or less emotional load, self-evaluation and modes of action that become typical in behavior and are used in everyday life. Detection of the problem of "I" in this aspect is devoted to a large number of studies. In these works it is traced that the person's own image and understanding of himself as a person and subject of activity changes in a person with the transition from one age to another, as well as depending on his gender, profession and belonging to a certain ethnic community with its traditions and culture (L. U. Borozdin, I. E. Vigerchuk, V. N. Kunitsyna, V. A. Labunskaya, B. A. Yermeev, Z. N. Lukyanova, N. U. Nakoshna, A. P. Okoneshnikova, A. A. Chekalin and others).

A significant phenomenon that is analyzed in the research of the characteristics of the "I", serves the role of personality in the regulation of 
behavior and activity (A. A. Malik-Pashayev, A. V. Suvorov, etc.). Individual can build his behavior and perform actions at the level of his own everyday self, but he can not carry out deeds at the level of his higher self. In most people, their everyday behavior is determined by the everyday life I, and it, for A. Maslow, is initiated by diverse needs. However, in critical or extreme situations, in some people, the regulation of behavior and activities begins to perform above "I", and at the same time they actualize domestic needs. At the same time, in these studies, people are described (a rather insignificant percentage), for which the basic values of life and culture have become their subjectively significant values, and their livelihoods are predominantly regulated by their higher self.

The study of modern special scientific literature shows that in the psychology of the individual certain prerequisites for deepening the theoretical and methodological analysis and justification of the category "Iconcept" (V. S. Agapov, B. G. Ananiev, A. G. Asmolov, I. B. Baryshnikov, A. A. Bodalev, A. V. Brushlinsky and others). It is a study of the problem of self-determination, self-esteem, self-determination, self-affirmation, the person's perception of himself in the conditions of joint activity, the influence of the I-concept on motivation, spiritual needs, value orientations, on the socio-psychological adaptation of the individual, the development of professional self.

Different theoretical views and methodological approaches to the study of the l-concept do not correlate with each other, since different scientists, based on their research on various tasks, come to contradictory views on these categories, their structural and content components. Many scholars consider the problem of the I-concept narrow-specialized, within its own specific scientific approach (socio-psychological, medical, and age). Often, the I-concept is considered by the researcher only as a component of another problem or included in different contexts. 
The concept of "personality" is wider than the concept "I-concept". In determining the I-concept in the structure of the individual must take into account the features of its functional load and content peculiarity. I-concept acts in this regard as a kind of integral of individual, special, subjectiveactivity characteristics. The development of a person depends on the Iconcept, which contains an integral assessment of the personality of his own abilities, desires, reserves, opportunities, the way of his objectification (life perspective, meaning of life, the goal is far and near). "I" is a concept for professional activity, "I" is perfect in professional activity.

The concepts of personality and self-concept are closely related to the concept of "self" - self-determination, self-knowledge, self-actualization, self-expression, self-esteem, self-realization of man (as a special system, which is inherent, along with the properties of self-development of any system, its own, specific, due only to it as a system of human and associated with its real "identity" properties) require a special analysis and understanding in its differentiated and integrated comprehension (not only at the individual level in the process of ontogenesis, but also as a phenomenon of filo origin and cultural and historical development), according to the realities of modern social state, the changing historical environment.

This is important as an assessment of the possibilities of preserving and creating the human world and of being in it as a carrier of a historically new level of organization - the realization of social movement.

According to the characteristics of E. V. llyenkov,: "... the scale of a individual's personality is measured only by the scale of those real tasks, in the course of which it arises, and is formalized in its certainty, and is considered in matters that concern and interest not only their own person, but and many other people. Therefore, the strength of the individual - it is always the individually expressed force of the collective, that "ensemble" of 
individuals, which is ideally represented in it, the power of the individualized community of aspirations, needs, goals that govern it "[6].

Any social assessment is an assessment of the environment of any manifestation, action or property, depending on its positive or negative attitude towards the general social norm. The social norm is common to the entire society. When this rule is applied by an individual in different situations and by different people in the same concrete situation, a large variety of individual assessments of the degree of observance or violation of the social norm arises. As a result, the correlation of social norms with specific situations creates different individual scales of assessments in accordance with the conditions of formation and development of personality. A general social assessment by the society becomes possible only when individual scales of grades are categorized into specific situations in which a social norm is applied, is reduced to several general categories. As a result, of such categorization there is a collective scale of social assessments.

Social perception is the basis of the intermediate state, depending on which the whole system of interpersonal interactions in the environment and the system of social mood is created. For the same properties of personality, value orientations, the social status of a person varies depending on how they are taken and evaluated by the environment. This dependence is clearly shown in the studies of G. M. Andreev: for the same psychodynamic properties, the sociometric status of the student varies at different stages of study [3].

Personality - an individual as a subject of social relations and conscious activity, the phenomenon of social development, a specific living person, who has a consciousness and self-awareness.

Consequently, the person can be considered as a form of integration of the human psyche in a somewhat holistic and sustainable within the social 
system and on a social basis. Then the activity of the subject ensures, firstly, the basis for the philosophical isolation of him from a number of other phenomena of reality, and secondly, fixes the mechanism of such a distinction, which is connected precisely with the quality of detection of activity. Depending on the specificity of human activity, its differentiation from the context of its existence will occur in different ways, but will necessarily take place while ensuring the isolation of the individual. Therefore, the subject is a way of differentiating a social person.

Valuably-semantic structure of the individual necessarily contains a number of characteristics that are related to the field of social acts. Their formation is connected with the objective social situation of the formation of the individual, as well as with the characteristic of value orientations, which is given by the subjective position of the individual. The social position is also significant, because through it "a person enters the system of social relations and begins its movement in the social concrete historical reality. The relation between the subject position and the social position of a person at different stages of personality development is different.

Active life position (subjective position) in relations with the social world as an integral characteristic of the individual, containing a number of properties and abilities, serves as the main link of social activity. The formation of the subjective position of the individual is related to the effects of socialization and the strengthening of the cognitive-evaluative function, when the autonomous level of self-management reaches a certain optimum and allows it to realize its activity in correlation not only with external instances, but also contrary to them, if it correlates with internal valuessemantic entities, beliefs.

Social activity of the individual is understood as a separate case of the initiative's influence of the subject on the environment. Social activity of the individual involves not only its participation in social life, but also the 
initiative-creative attitude to the spheres of its social life, as well as to itself as a subject of social life. According to A. B. Kupreychenko and A. S. Moiseyev, social activity is "individual or group actions aimed at changing society in general, its place in it and itself (I-social)" [7, p.72].

Social activity of the individual is mediated by its subjectivity, which is the instance of realization of intentions given by the person. The level of activity, its productivity, and success associated not only with the corresponding level of personality development, but also with the development of it as a subject.

Different levels of social activity are distinguished - personal, interpersonal, personal-group, personal-institutional, etc.

K. A. Abulkhanova-Slavskaya [1] emphasizes that the main forms of manifestation of activity, serving the socio-psychological characteristics of the individual, is the initiative and responsibility.

In the heart of social activity of the person lies the system of subjective relations. In relations, there are a number of characteristics of the perception of the surrounding world, from which formed a complete representation of it. Moreover, the peculiarity of this reflection is the preference of the individual, their ability to emotional assessment, correlation with previous impressions, assimilated norms, settings, and even the very properties of the individual. B. F. Lomov believed that these relations show how the person relates to certain events and phenomena of the world in which he lives (they show value orientations, preferences, sympathies, antipathies, interests, etc.). According to B. F. Lomov [8], the system of these relations is a complex, multilevel, dynamic entity, which can be described as a multidimensional subjective "space", each dimension of which corresponds to a certain subjective-personal relation (to work, property, other people, political events, etc.). 
The main condition of social activity is the orientation of the individual an integral characteristic, which combines those socio-psychological education, which collectively become the causative agents of socially oriented action, since the implementation of the direction is carried out by the motivational sphere.

The study of the interaction of personality and situation involves the study of three main sections: the peculiarities of human situations in the relationship of situational and personal variables; subjective interpretation of situations, behavioral strategies and other forms of activity within specific situations [4].

According to the well-known formula of determinism, S. L. Rubinstein's external situation operates through the prism of internal conditions [12]. These include as subjective individual representations of the subject of his life's way of what he is and how he should be.

The modern direction of acmeological research, in the aspect of studying the influence of man's representations of self (I-concept) on the development of his as a subject of activity, is to study the acmeological foundations of the professional development of a specialist. A professional position is determined by the unity of a person's attitude towards the world of his profession (subject of work, colleagues, the person in this profession, the result of work and professional growth), attitudes, expectations and readiness for professional growth [2; 5]. The development of a professional position is determined by various parameters of professional selfawareness, in particular the dynamics of the image of "I" during training and in the process of self-development.

The main role in the development, growth of the person is not the results of their activity, but their psychological re-processing of the person, the formation of the inner world of individual, when the true, necessary meaning of his life and activities is revealed. A. Maslow wrote: "Self- 
realization is not something that one can have or not have. This is a process that does not end ... This is a way of life, a way of working and a relation to the world, and not a single achievement " [10, p.82].

The most complete disclosure of human abilities is possible only in socially significant activities. It is important here that the realization of this activity should be determined not only externally (by society), but also by the internal need of the personality in it. The activity of an individual in this case becomes an amateur, and the realization of its abilities in a certain activity has the character of self-realization.

Professional self-realization is based on the following factors: selfactualization, self-determination and self-regulation.

The concept of self-actualization includes the main idea expressed by A. Maslow [10] about the human desire to realize all its potential capabilities and abilities. In the concept of S. L. Rubinstein also laid the notion of selfactualization, as a category of "orientation" [13, p. 68].

The process of self-actualization involves all areas of the individual's life, but it is particularly manifested in professional activity. Self-actualization involves realizing a person's abilities together with realization of personal potential.

Professional growth is understood as gaining new knowledge, skills and skills by expanding the number of situations in which they are needed.

Personal growth is an approximation to the understanding and realization of the meaning of one's own life through the acquisition of personal experience, which includes self-knowledge through the acquisition of universal values.

On the basis of the sociological approach, self-determination is considered in relation to the generation at large and characterizes its entry into certain social structures and spheres of life and their stabilization in these social structures. 
Conclusions. The professional socialization of the individual is determined by the intensity, depth and diversity of interrelations. Under the professional socialization of the future teacher-pedagogue we mean mastering the socio-professional experience in a purposeful, specialized organization, which manifests itself as a set of all educational influences. Pedagogical activity is characterized by a focus on others, orientation on social norms. Therefore, the professional socialization of the teacher has its own specificity, which manifests itself primarily in reducing self-actualization and increasing prosociality.

\section{References:}

1. Abulkhanova-Slavskaya K. A. Psikhologiya i soznanie lichnosti (problemy metodologii, teorii i issledovaniya realnoy lichnosti): izbr. psikhol. tr. / K. A. Abulkhanova-Slavskaya. - M.; Voronezh, 1999. - 224 s.

2. Agapov V. S. Ya-kontseptsiya v strukture upravlencheskoy deyatelnosti/ V. S. Agapov. - M,:GUU, 1999.

3. Andreeva G. M. Sotsialnaya psikhologiya / G. M. Andreeva. - M.: Izd-vo Mosk. un-ta,1980. - $416 \mathrm{~s}$.

4. Burlachuk L.F. K psikhologicheskoy teorii situatsii: vzaimodeystvie cheloveka s situatsiey / L. F. Burlachuk, N. B. Mikhaylova // Psikhol. zhurn. - 2002. - T.23, № 1.

5. Derkach A. A. Akmeologiya v sisteme nauk o cheloveke / A. A. Derkach// Teoriya i metodologiya psikhologii: Postneklassicheskaya perspektiva / otv.red. A. L. Zhuravlev, A.V.Yurevich. - M., 2007.

6. Ilenkov E. V. Chto takoe lichnost? / E.V.Ilenkov // S chego nachinaetsya lichnost. - M.: Izd. Polit. Lit., 1984. - S. 319-358.

7. Kupreychenko A. B. Sotsialnoe samoopredelenie rossiyskogo gorodskogo srednego klassa / A. B. Kupreychenko, A. S. Moiseev // Uchen. zap. IMEI. - 2011 yu - № 2 (2). - S.71-84. 
8. Lomov B. F. Sistemnost v psikhologii: izbr. psikhol. tr./ B. F. Lomov. - M.; Voronezh, 2003. - $424 s$.

9. Makarenko A. S. Izbr. Proizvedeniya: V 8-i t. / A. S. Makarenko. - M.: Pedagogika, 1984.

10. Maslou A. Motivatsiya i lichnost / A. Maslou. - SPb.: Yevraziya, 1999. $478 \mathrm{~s}$.

11. Pilipovskiy V. Ya. Vstupitelnaya statya // R. Berns. Ya-kontseptsiya $i$ vospitanie. - M., 1985.

12. Rubinshteyn S. L. Izbrannye filosofsko-psikhologicheskie trudy. Osnovy ontologii, logiki i psikhologi / S. L. Rubinshteyn. - M., 1997.

13. Rubinshteyn S. L. Osnovy obshchey psikhologii: $v 2$ t. / S. L. Rubinshteyn. - M.: Pedagogika, 1989. - T. 1.

14. Salliven G. S. Mezhlichnostnaya teoriya psikhiatrii / G. S. Salliven // Istoriya zarubezhnoy psikhologii / [red. P. Ya. Galperin, A. N. Zhdan]. - M., 1986. - S. $172-185$.

15. Sokolova Ye. Ye. Idei A.N. Leonteva i ego shkoly o postupke kak edinitse analiza lichnosti $v$ ikh znachenii dlya istoricheskoy psikhologii / Ye. Ye. Sokolova //Traditsii $i$ perspektivy deyatelnostnogo podkhoda $v$ psikhologii. - M., 1999.

16. Filippova L. V. Sotsializatsiya lichnosti i pedagogicheskaya deyatelnost obshchestva: Dis. ... kand.filos. nauk. - Perm, 1985.

17. Filippova L. V. Filosofsko-pedagogicheskie osnovy valeologii / L. V. Filippova. - N. Novgorod, 2000. 